\title{
Potential of Flocculant-Aided Soil Slurry Dewatering in Land Reclamation: Laboratory Investigations
}

\author{
Yang Jiao, ${ }^{1,2}$ Jia He $\mathbb{D}^{1,2}$ Peiyuan Zhou, ${ }^{1,2}$ and Ziqian $\mathrm{Cao}^{3}$ \\ ${ }^{1}$ Key Laboratory of Ministry of Education for Geomechanics and Embankment Engineering, Hohai University, \\ Nanjing 210098, China \\ ${ }^{2}$ Jiangsu Research Center for Geotechnical Engineering and Technology, Hohai University, Nanjing 210098, China \\ ${ }^{3}$ Lanfang Environmental Technology (Tianjin) Co. Ltd., Tianjin 300300, China \\ Correspondence should be addressed to Jia He; hejia@hhu.edu.cn
}

Received 21 June 2018; Accepted 19 September 2018; Published 14 October 2018

Academic Editor: Damien Rangeard

Copyright (C) 2018 Yang Jiao et al. This is an open access article distributed under the Creative Commons Attribution License, which permits unrestricted use, distribution, and reproduction in any medium, provided the original work is properly cited.

\begin{abstract}
When soil slurry is used as a fill material in land reclamation projects, vacuum preloading or geotextile tube systems are often adopted for the dewatering treatment in a large scale. However, these two methods often suffer from clogging problems and impede further dewatering treatment. In this study, we test the potential of using flocculants to enhance the dewatering efficiency in a vacuum preloading model test and a geotextile tube model test. Experimental results show that, by adding a flocculant into soil slurry, the dewatering efficiency in terms of drainage volumes and rates is significantly improved as compared to that in pure soil slurry. The amounts of drainage water in the tests with flocculant addition are about $20 \%$ and $100 \%$ more than those in pure slurry tests in the vacuum preloading and geotextile tube model tests, respectively. The underlying reason could be the flocculation effect that prevents the movement of small soil grains and the formation of impermeable layers on the filters.
\end{abstract}

\section{Introduction}

To cater the industrial and urban development, large-scale foreshore land reclamation projects have been taking place in coastal regions in many East Asian countries. In the engineering practices in China, seabed soils are widely used as fill materials in land reclamation projects [1]. Seabed soils are easily obtained at coastal regions. A common way to facilitate the transportation of seabed soils is to mix soils with large amounts of water using cutter suction dredgers and transport the soil slurry though pipelines. In spite of the convenience and cheapness to obtain fill materials in such a way, the subsequent dewatering process is difficult and time-consuming.

Two techniques are usually used for the dewatering of soil slurry in land reclamation projects: the vacuum preloading and geotextile tube systems [1]. The vacuum preloading system is briefly illustrated in Figure 1. It mainly consists of a drainage system and a vacuum pumping system. The drainage system comprises vertical drains installed vertically in the soil and horizontal drains that can transfer vacuum pressure into the soil ground. Under the vacuum pressure, water and gas in the soil can be taken away, and thus, soil can be compressed like a sponge. The vacuum preloading technique is suitable for the creation of land spaces in large areas. The use of geotextile tubes for the dewatering of soil slurry is illustrated in Figure 2. The material used to fabricate the tubes has high tensile strength and stiffness. It also serves as a filter for the drainage of water. Soil slurry is pumped into the tube first. When the tube is full, further pumping of slurry into the tube can cause high pressure and in turn lead to the drainage of clean water from the tube surface. Several tubes can be stacked together to accelerate the dewatering process. Geotextile tube systems are often used for the construction of dikes, breakwaters, and other temporary and permanent shore protection structures.

In spite of the extensive adoption in engineering practices, a serious problem in these two dewatering techniques is that the drainage capacity can be greatly reduced due to the clogging of vertical drains/geotextiles, as reported by 


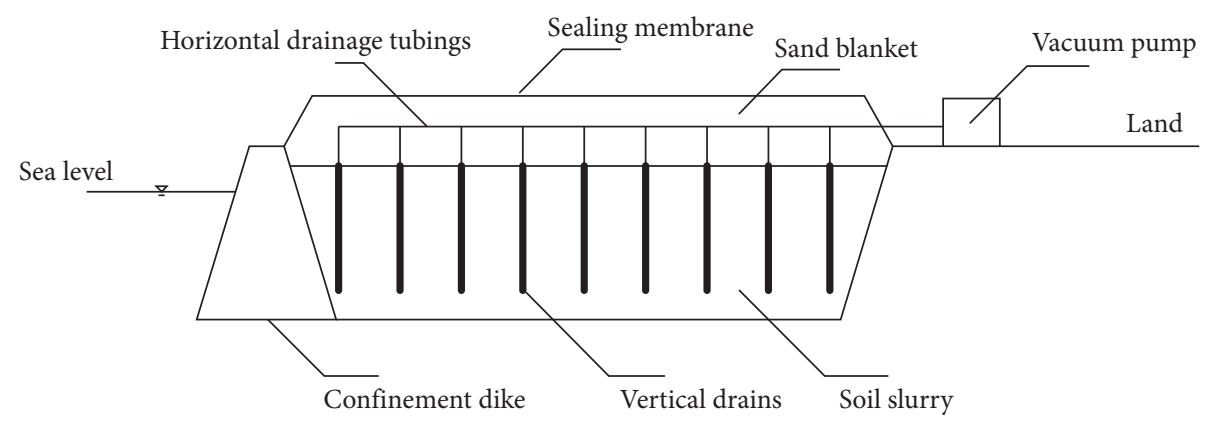

Figure 1: Vacuum preloading system.

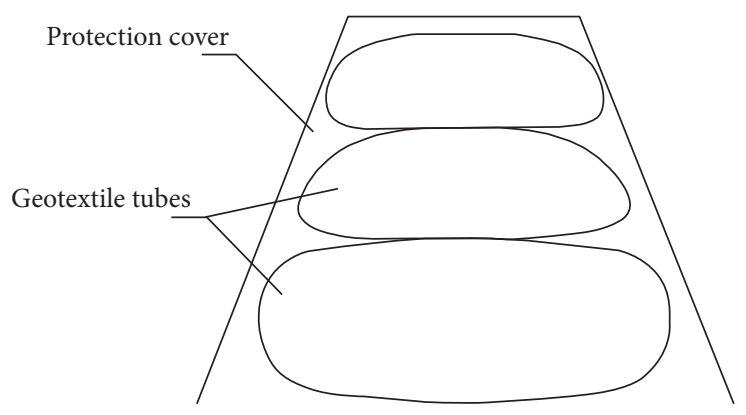

FIGURE 2: Illustration of geotextile tubes as a shore protection structure.

many studies and engineering projects $[2,3]$. During the dewatering processes, small soil grains can flow with water and finally adhere onto the filter. A thin layer of small grain soils on the filter could be the major reason that accounts for the reduction of drainage capacity.

One of the possible solutions to the abovementioned problem is to use flocculants. Flocculants are a type of longchain organic compounds of repeating monomers. Monomers are the single units that consist of flocculant molecules. In the water environment, flocculants can attract fine solid particles and form large aggregates (i.e., flocs), as illustrated in Figure 3. Using flocculants is an effective way to remove small particles in water or to enhance the dewatering efficiency of slurry materials. It is widely used in wastewater treatment facilities. It has also received increasing interests in other applications, such as the management of tailings from oil sand mining $[5,6]$ and the dewatering of dredged sediments $[7,8]$. The use of flocculants in geotechnical engineering for land reclamation and ground improvement projects has been receiving research interests in recent years [2-4].

In this study, attempts were made to evaluate the potential of using flocculants for the dewatering of soil slurry. Two laboratory model tests, vacuum preloading and geotextile tube tests, were carried out. The dewatering effects were evaluated in comparison to those without flocculant addition. The underlying mechanisms are also discussed.

\section{Materials and Test Methods}

2.1. Testing Materials. Testing soil was obtained from a staging ground used for the placement of dredging sediments from Baimahu Lake, Jiangsu Province, China. Basic physical and geotechnical properties of the soil are given in Table 1. The experiments for the determination of these index properties followed the Chinese standard for soil testing [9]. An SEM image of the soil is presented in Figure 4. Based on the X-ray diffraction analysis, the chemical composition of the soil was $84.23 \% \mathrm{SiO}_{2}, 7.12 \% \mathrm{Al}_{2} \mathrm{O}_{3}, 5.32 \%$ $\mathrm{Fe}_{3} \mathrm{O}_{4}$, and $3.33 \% \mathrm{CaO}$. The soil mainly consisted of quartz and vermiculite.

In this study, polyacrylamide (PAM) was used for the treatment of soil slurry. PAM is a commonly used flocculant in wastewater treatment facilities. The PAM used in the experiments was nonionic. The molecular weight was 12 million. There are many types of flocculants with different parameters, including the types of charge (cationic, anionic, or neutral), the charge density (quantity of positive or negative charge), the molecular weight, the molecular structure, and the type of monomers $[10,11]$. This flocculant was selected because it was the most effective one in accelerating the settlement of soil slurry compared with several other flocculants with different parameters. Details of the methods for the selection of a proper flocculant in a particular condition were given in [4].

2.2. Preparation of Soil Slurry. Soil slurry was prepared by adding ultrapure water into the soil and mixing them to a uniform state. The flocculant should be used in the solution form. Dry granules of the flocculant were added into ultrapure water at $0.4 \%$ concentration, and mixing was carried out for 1 hour to ensure complete dissolving. For the treatment of soil slurry, flocculant solution was added into 


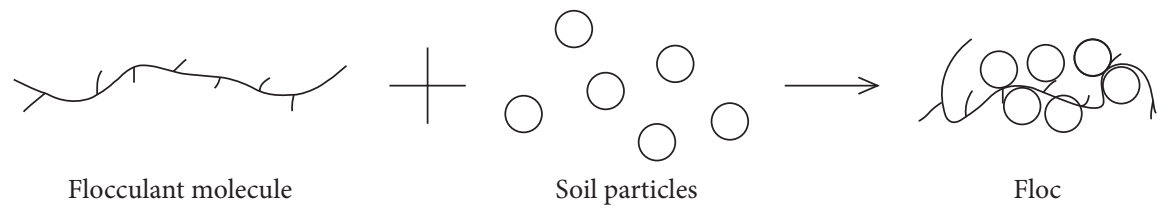

Figure 3: Illustration of the function of flocculants (adapted from [4]).

Table 1: Properties of the testing soil.

\begin{tabular}{|c|c|c|c|c|c|c|c|c|c|}
\hline \multirow[b]{2}{*}{ Location } & \multicolumn{3}{|c|}{ Grain size distribution (\%) } & \multirow[b]{2}{*}{$\begin{array}{l}\text { Specific } \\
\text { gravity }\end{array}$} & \multirow{2}{*}{$\begin{array}{c}\text { Plastic } \\
\text { limit } \\
(\%)\end{array}$} & \multirow{2}{*}{$\begin{array}{l}\text { Liquid } \\
\text { limit } \\
(\%)\end{array}$} & \multirow{2}{*}{$\begin{array}{c}\text { Organic } \\
\text { content } \\
(\%)\end{array}$} & \multirow[b]{2}{*}{$\begin{array}{l}\text { Compression } \\
\text { index* }\end{array}$} & \multirow{2}{*}{$\begin{array}{c}\text { Permeability* } \\
(100 \mathrm{kPa} \\
\text { overburden } \\
\text { pressure })(\mathrm{cm} / \mathrm{s})\end{array}$} \\
\hline & $\begin{array}{c}\text { Sand } \\
(0.075-2 \mathrm{~mm})\end{array}$ & $\begin{array}{c}\text { Silt } \\
(0.005-0.075 \mathrm{~mm})\end{array}$ & $\begin{array}{c}\text { Clay } \\
(<0.005 \mathrm{~mm})\end{array}$ & & & & & & \\
\hline $\begin{array}{l}\text { Baimahu } \\
\text { Lake, Jiangsu, } \\
\text { China }\end{array}$ & 3.3 & 50.6 & 46.1 & 2.65 & 27.9 & 65.3 & 3.83 & 0.775 & $1.4 \times 10^{-8}$ \\
\hline
\end{tabular}

*The values of compression index and permeability were obtained from the oedometer tests on the resedimenting soil with the initial water content of $134.0 \%$.

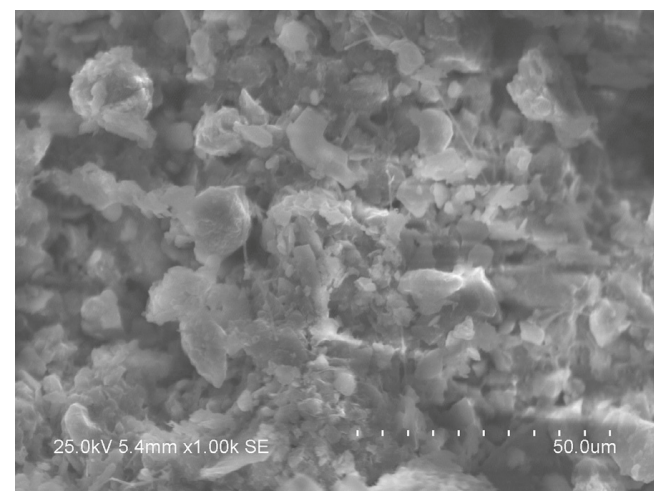

Figure 4: SEM image of the testing soil.

soil slurry at a ratio of dry flocculant: dry soil $=1: 2000$ by weight. The initial water contents were $100 \%$ for both pure slurry and flocculant-added slurry. The methods and procedures of applying flocculants into soil slurry also followed our previous study [4].

2.3. Vacuum Preloading Model Test. The setup of the vacuum preloading model is illustrated in Figure 5. The prefabricated vertical drain was produced by Quansheng Electronics Co. Ltd. (China). It had a maximum drainage capacity of $50 \mathrm{~cm}^{3} / \mathrm{s}$. The inner diameter of the test container was $43 \mathrm{~cm}$. Both pure soil slurry and flocculant-added soil slurry were prepared before placing into the container. After the preparation, the soil slurry was carefully poured into the container to avoid any inclusion of gas bubbles. The slurry was filled to a height of $55 \mathrm{~cm}$. A piston was placed on top of the slurry surface. The piston could move freely up and down to adjust to the settlement of soil slurry. A vertical drain was inserted into the slurry sample for transferring vacuum pressure. The top end of the vertical drain was connected to a sealed water tank. A vacuum pump was also connected to the water tank for the application of vacuum pressure into the vertical drain and soil slurry. During the application of vacuum pressure, soil slurry experienced compression and consolidation under the pressure difference below and above the piston. The settlement of the slurry was measured using the ruler attached to the container. Water flowed out of the slurry was collected in the water tank. The volume of drainage water can be measured using a balance during the tests.

2.4. Geotextile Tube Model Test. The setup of the geotextile tube test is illustrated in Figure 6. The geotextile tube was SoilTain PP 105 produced by Huesker Synthetic GmbH. The tensile strength was larger than $105 \mathrm{kN} / \mathrm{m}$. The permeability in the vertical direction was $20 \times 10^{-3} \mathrm{~m} / \mathrm{s}$. The size of the geotextile tube was $110 \times 72 \mathrm{~cm}^{2}$. During the test, slurry was pumped into the tube until it became completely full. Then, the slurry underwent drainage and settlement under its self-weight for around 1 day. After 1 day, $60 \mathrm{~kg}$ sand bags were placed on top of the geotextile tube to further compress the slurry for several days until there was no more water drained out. The settlement of the geotextile tube at its top point was measured. The drainage water could be collected, and its weight could be measured using a balance during the tests.

\section{Results}

3.1. Vacuum Preloading Tests. Two vacuum preloading tests were carried out on pure slurry and flocculant-added slurry, respectively. During the tests, vacuum pressure was maintained higher than $90 \mathrm{kPa}$. Figure 7 shows the weight of drainage water during the tests. The test with flocculant addition showed a larger drainage amount and a faster drainage rate than that without flocculant. At the end of the tests, the amount of drainage water in the flocculated slurry was about $20 \%$ more than that in the pure slurry. The settlement curves are shown in Figure 8. Flocculant-added slurry showed a larger and faster settlement than pure slurry. The settlement curves (Figure 8) did not match water drainage curves (Figure 7). This could be due to the development of cracks in the slurry samples. 


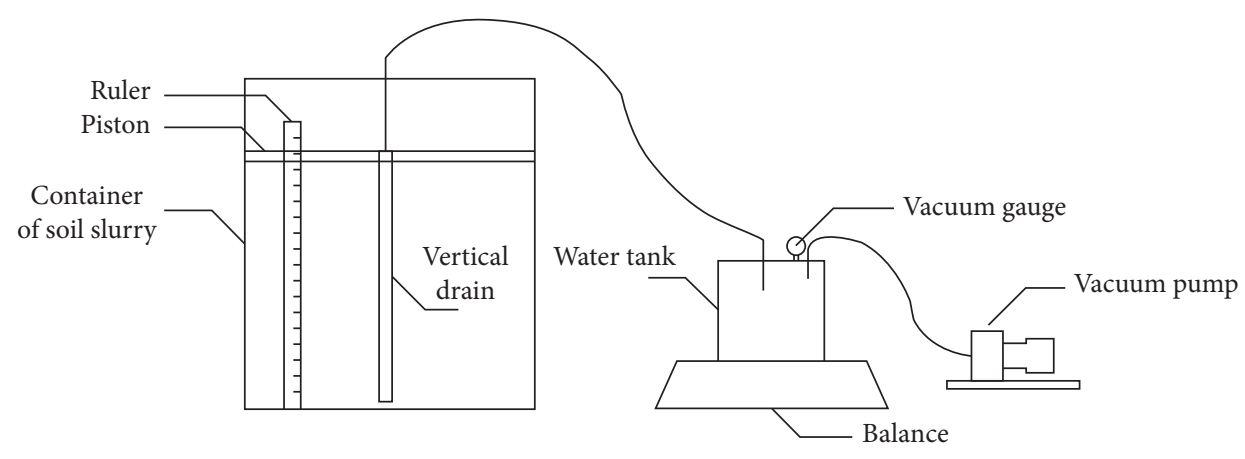

FIGURE 5: Schematic of the vacuum preloading test model.

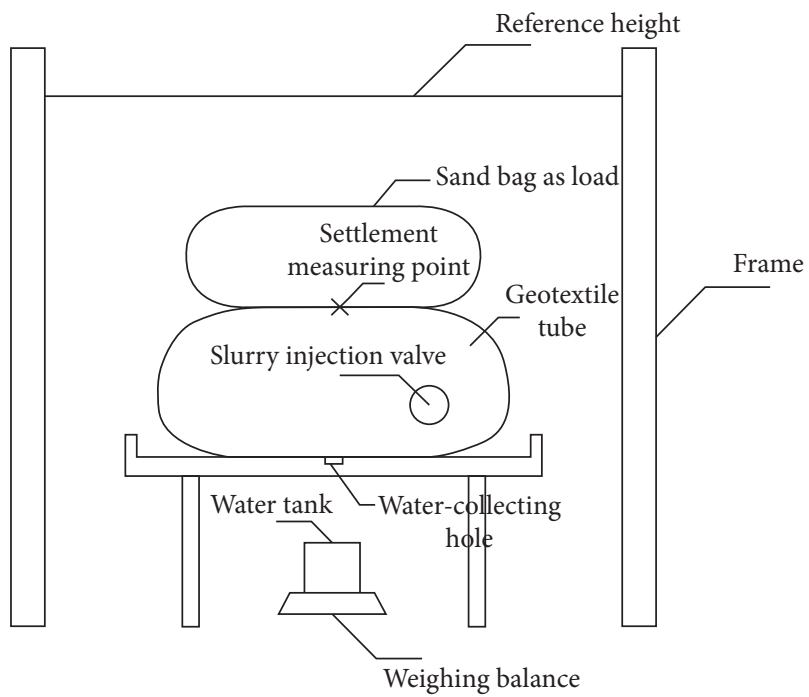

Figure 6: Schematic of the geotextile tube test model.

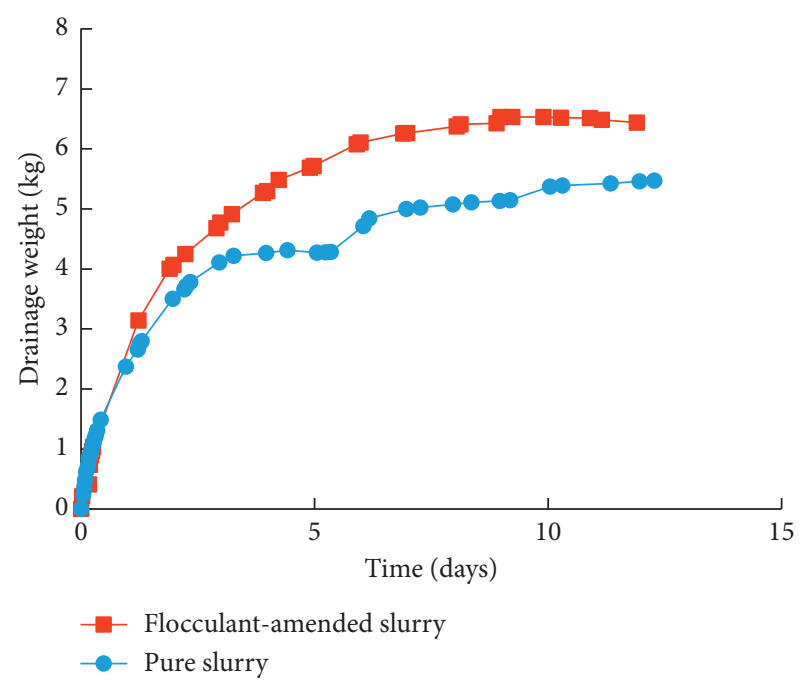

Figure 7: Drainage weight versus time in the vacuum preloading test.

3.2. Geotextile Tube Tests. When geotextile tubes are used for the dewatering of slurry, the addition of flocculant into the slurry also has beneficial effects in terms of dewatering

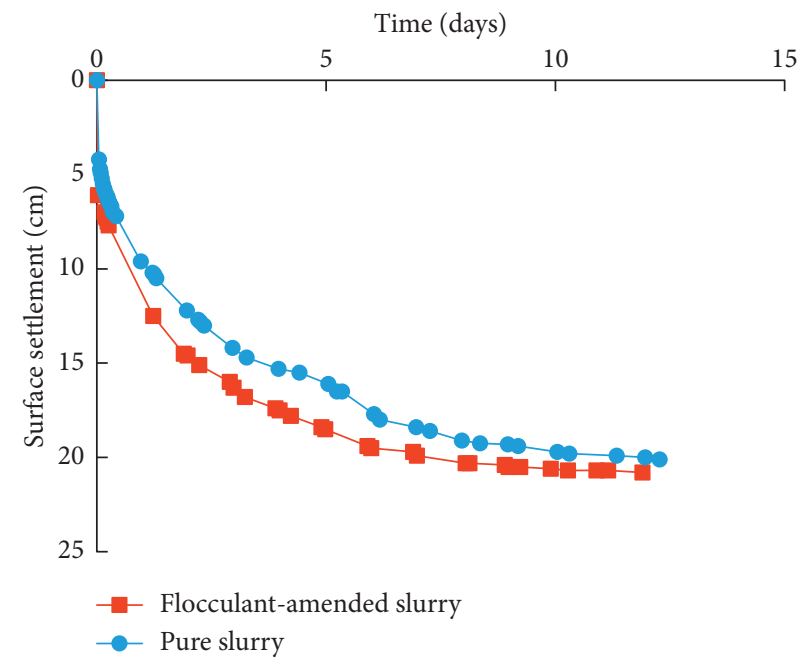

FIgURE 8: Settlement versus time in the vacuum preloading test.

volume and rate. Figure 9 shows the amount of drainage water during the tests. The amount of drainage water in the flocculant-added test was about twice that in the pure slurry test. The settlement of the flocculant-added geotextile tube was also much larger than that of the pure slurry tube, as can be seen in Figure 10.

\section{Discussions}

It has been presented above that the use of flocculants can significantly improve the performance of slurry dewatering in the vacuum preloading and geotextile tube systems. The mechanisms are discussed here. When a flocculant is added into soil slurry, small grains in the slurry tend to attract together and form flocs (assemblage of grains). One example is given here [4]. As can be seen in Figure 11, when adding a flocculant into soil slurry, flocs can be formed which are much larger than single soil grains. As for the use of vacuum preloading or geotextile tubes, smaller soil grains tend to flow with water and finally attach to the filter. As a result, an impermeable layer consisting of fine grain soils can be formed on the filter, leading to the reduction in the drainage capacity. This process is explained in Figure 12(a). However, when a flocculant is added into the slurry, small soil grains can be captured by flocculant chains, and thereby, the 


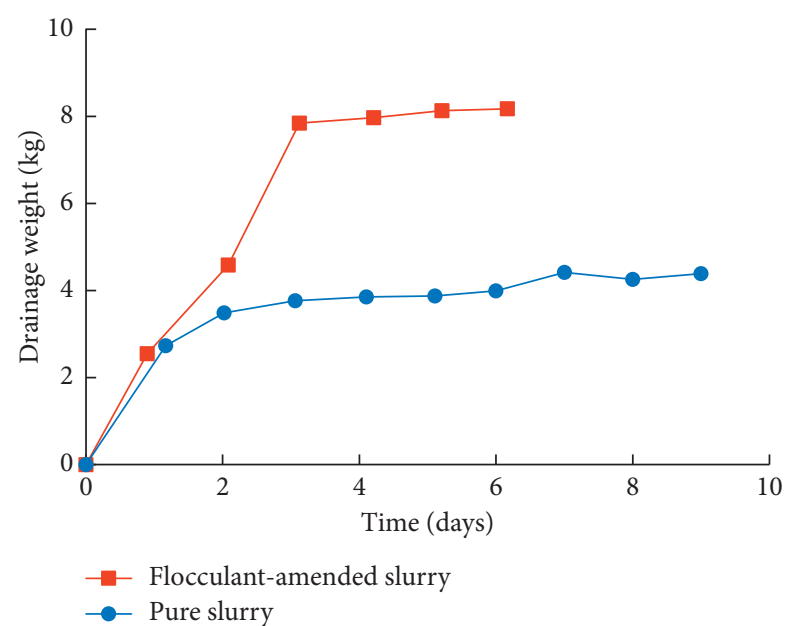

FIGURE 9: Drainage weight versus time in the geotextile tube test.

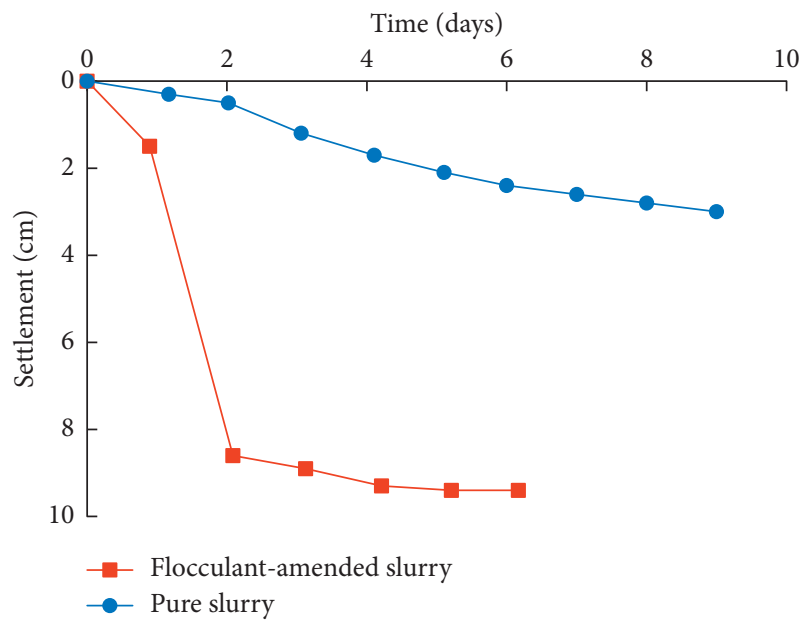

Figure 10: Settlement versus time in the geotextile tube test.

clogging of the filter can be prevented or alleviated, as illustrated in Figure 12(b).

An interesting finding from comparisons between the two tests is that when a flocculant is added, the dewatering effects in the geotextile tube are much more significant than those in the vacuum preloading. Such a difference could be because of the pressure on the drainage boundaries. In the geotextile tube, excess pore pressure generated in the soil can be dissipated easily at the drainage boundary. In the vacuum preloading, negative vacuum pressure is maintained at the boundary, which could lead to the migration of soil grains onto the drains and finally cause the degradation of drainage capacity, in spite of the use of flocculants. An indirect evidence provided in [12] shows that, in the vacuum preloading method, by increasing the vacuum pressure stepwise to the maximum value instead of applying it instantaneously, the drain clogging problem can be alleviated. In future studies, attempts can be made by adding more flocculants in soil slurry or applying vacuum pressure slowly and stepwise to explore whether the drainage efficiency can be improved.

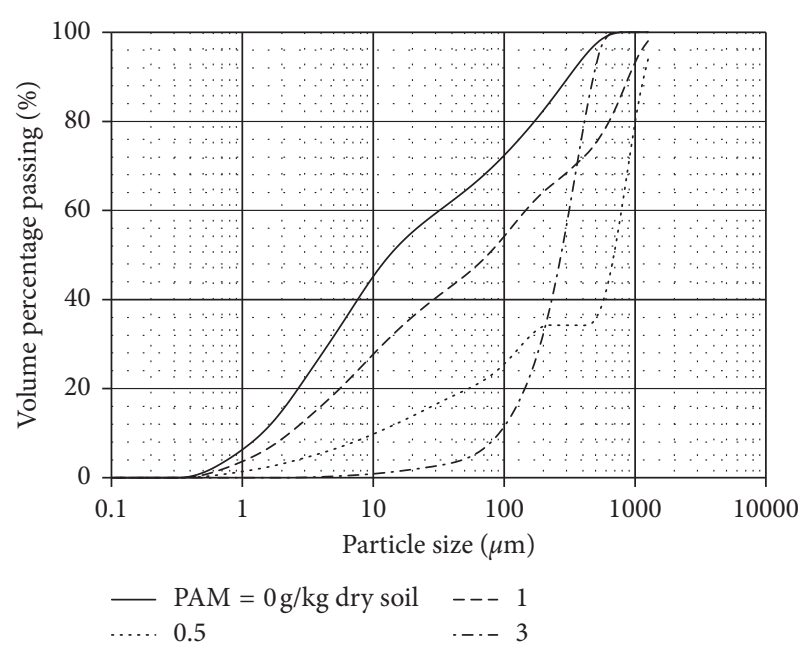

FIGURE 11: Particle size distributions of pure soil and flocculantadded soil (data from [4]).

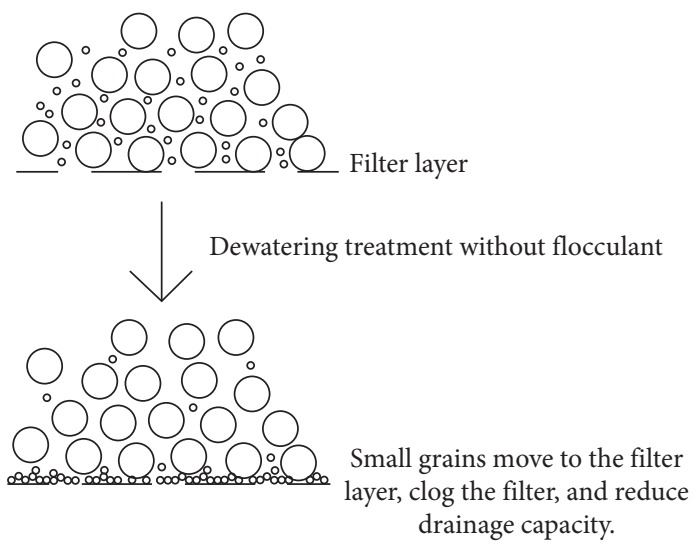

(a)

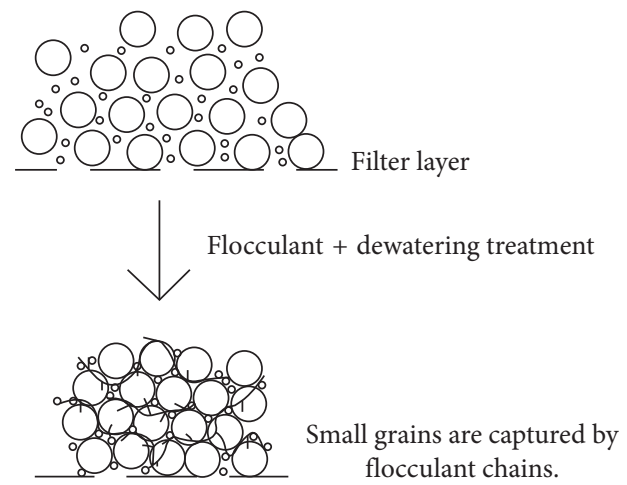

(b)

Figure 12: Proposed mechanism of flocculant-aided dewatering in vacuum preloading and geotextile tube. (a) Dewatering without flocculant addition. (b) Dewatering with flocculant addition.

It is worth taking a note that although flocculants can enhance the dewatering efficiency of soil slurry, the mechanical behaviour and geotechnical properties of flocculant-amended soil after the sedimentation are different from those of soil without any flocculant addition $[5,6]$. 
Flocculant-amended soil starts to develop shear strength at a water content higher than pure soil during the sedimentation process. The sensitivity of flocculant-amended soil is also higher than that of pure soil. These issues should be addressed in the subsequent ground improvement works.

\section{Conclusions}

In this paper, we study the potential of using flocculants to enhance the dewatering efficiency in the vacuum preloading and geotextile tube systems. In the vacuum preloading model test, by adding a flocculant into soil slurry, the volume of drainage water can be increased by $20 \%$ and the drainage rate can also be improved as compared with the pure slurry test. In the geotextile tube model test, the volume of drainage water in flocculant-added slurry doubles as compared with that of pure slurry. The settlement is also much larger than that of pure slurry tube. The improved performance of flocculant-aided dewatering can be explained by the flocculation effect. Without the addition of flocculant, small soil grains tend to move to the filter and finally form an impermeable layer on the filter. The addition of flocculant into soil slurry leads to the formation of flocs (assemblage of soil grains), and thereby, the movement of small soil grains can be restricted. The drainage capacity can thus be maintained for a much longer period.

\section{Data Availability}

The data used to support the findings of this study are available from the corresponding author upon request.

\section{Conflicts of Interest}

The authors declare that they have no conflicts of interest.

\section{Acknowledgments}

This work was financially supported by the National Natural Science Foundation of China (No. 51608169) and the Jiangsu Provincial Natural Science Foundation of China (No. BK20150814).

\section{References}

[1] J. Chu, S. Yan, and K. P. Lam, "Methods for improvement of clay slurry or sewage sludge," Ground Improvement, vol. 165, no. 4, pp. 187-199, 2012.

[2] Y. Wu, Y. Lu, K. Niu, and D. Sun, "Experimental study on solid-liquids separation of construction waste slurry by additive agent-combined vacuum preloading," Chinese Journal of Geotechnical Engineering, vol. 39, no. 3, pp. 525-533, 2017.

[3] S. Zhao, F. Zeng, J. Wang, H. Fu, and Y. Wang, "Experimental study of flocculation combined with vacuum preloading to reinforce silt foundation," Chinese Journal of Rock Mechanics and Engineering, vol. 35, no. 6, pp. 1291-1296, 2016.

[4] J. He, J. Chu, S. K. Tan, T. T. Vu, and K. P. Lam, "Sedimentation behavior of flocculant-treated soil slurry," Marine Georesources \& Geotechnology, vol. 35, no. 5, pp. 593-602, 2017.
[5] N. Beier, W. Wilson, A. Dunmola, and D. Sego, "Impact of flocculation-based dewatering on the shear strength of soil sands fine tailings," Canadian Geotechnical Journal, vol. 50, no. 9, pp. 1001-1007, 2013.

[6] Y. Yao, F. van Tol, and L. van Paassen, "The effects of flocculant on the geotechnical properties of mature fine tailings: an experimental study," in Proceedings of the Third International Oil Sands Tailings Conference, Edmonton Alberta, December 2012.

[7] M. Englis and W. Hunter, "A description of sediment dewatering methods," in Proceedings of WODCON XVIII, Lake Buena Vista, FL, USA, May-June 2007.

[8] D. W. Hunter, M. Heard, and K. B. Baron, "The positive impact of polymers on sediment treatment and handling," in Proceedings of 38th Annual Texas A\&M Dredging Conference, San Diego, CA, USA, June 2006.

[9] Ministry of Housing and Development, China, Standard for Soil Test Method. GB/T 50123-1999, Ministry of Housing and Development, China, 1999.

[10] W. Brostow, H. E. H. Lobland, S. Pal, and R. P. Singh, "Polymeric flocculants for wastewater and industrial effluent treatment," Journal of Materials Education, vol. 31, no. 3-4, pp. 157-166, 2009.

[11] J. Pillai, "Flocculants and coagulants: the keys to water and waste management in aggregate production," 1997, http://www. aniq.org.mx/pqta/pdf/Flocculants $\% 20$ and\%20Coagulants $\%$ 20NALCO\%20(LIT).pdf.

[12] K. Xu, S. Lin, Z. Geng, and R. Han, "Experimental study on effects of vacuum loading modes on clogging of drainage board filtration membranes," Chinese Journal of Geotechnical Engineering, vol. 38, no. 2, pp. 123-129, 2016. 


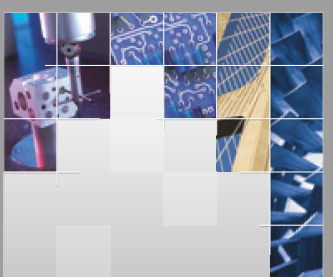

\section{Enfincering}
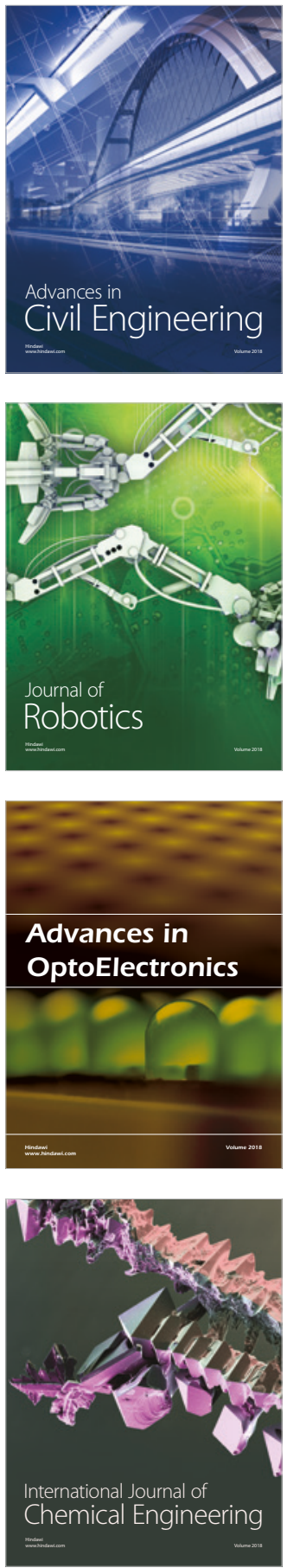

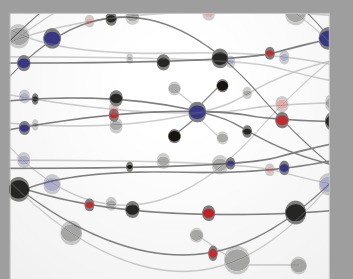

\section{Rotating \\ Machinery}

The Scientific World Journal

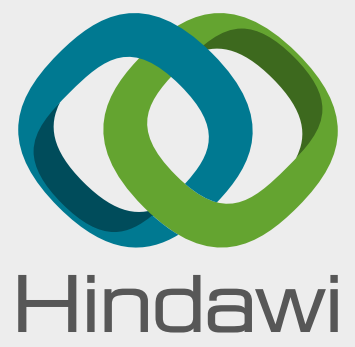

Submit your manuscripts at

www.hindawi.com
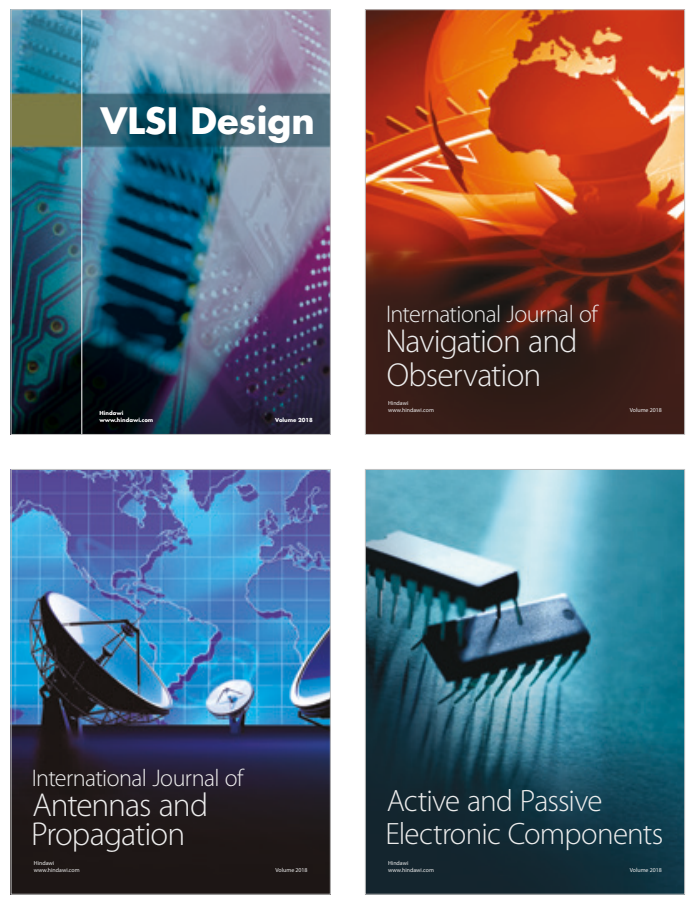
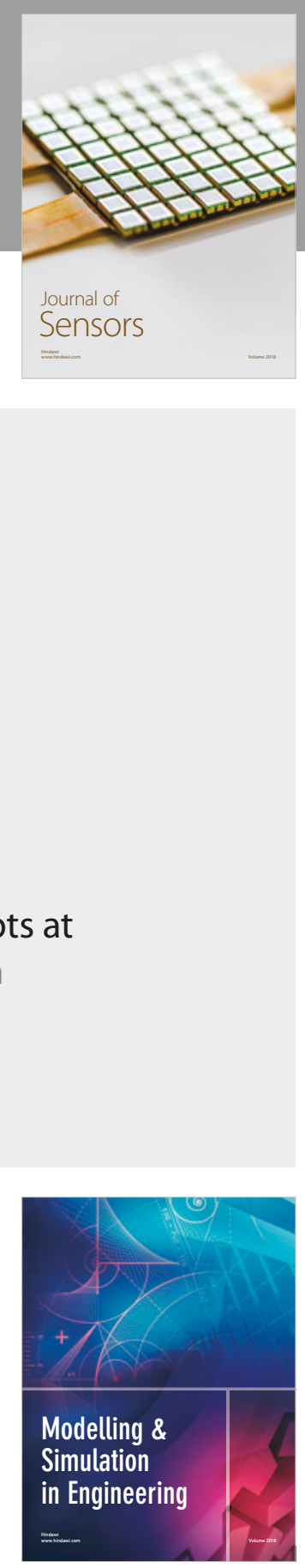

\section{Advances \\ Multimedia}
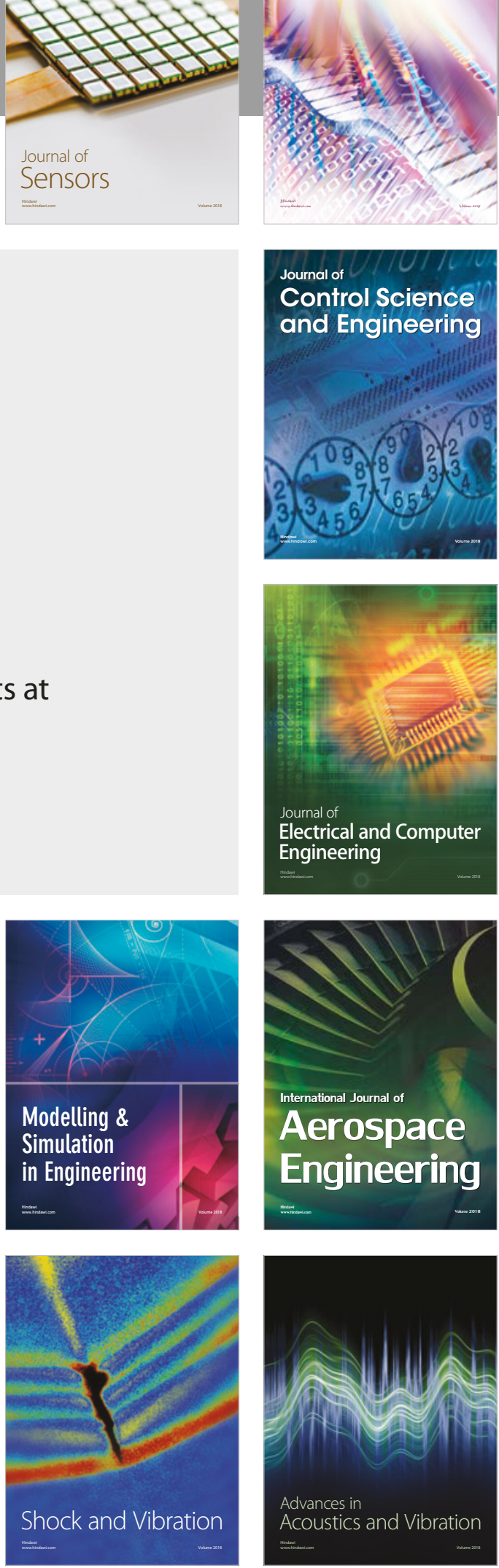